\title{
Atherosclerosis development
}

Citation for published version (APA):

van Kuijk, K., Baker, A. H., \& Sluimer, J. C. (2017). Atherosclerosis development: lipoproteins and beyond. Current Opinion in Lipidology, 28(6), 520-521. https://doi.org/10.1097/MOL.0000000000000462

Document status and date:

Published: 01/12/2017

DOI:

10.1097/MOL.0000000000000462

Document Version:

Publisher's PDF, also known as Version of record

Document license:

Taverne

Please check the document version of this publication:

- A submitted manuscript is the version of the article upon submission and before peer-review. There can be important differences between the submitted version and the official published version of record.

People interested in the research are advised to contact the author for the final version of the publication, or visit the DOI to the publisher's website.

- The final author version and the galley proof are versions of the publication after peer review.

- The final published version features the final layout of the paper including the volume, issue and page numbers.

Link to publication

\footnotetext{
General rights rights.

- You may freely distribute the URL identifying the publication in the public portal. please follow below link for the End User Agreement:

www.umlib.nl/taverne-license

Take down policy

If you believe that this document breaches copyright please contact us at:

repository@maastrichtuniversity.nl

providing details and we will investigate your claim.
}

Copyright and moral rights for the publications made accessible in the public portal are retained by the authors and/or other copyright owners and it is a condition of accessing publications that users recognise and abide by the legal requirements associated with these

- Users may download and print one copy of any publication from the public portal for the purpose of private study or research.

- You may not further distribute the material or use it for any profit-making activity or commercial gain

If the publication is distributed under the terms of Article $25 \mathrm{fa}$ of the Dutch Copyright Act, indicated by the "Taverne" license above, 


\section{Atherosclerosis development: lipoproteins and beyond}

Kim van Kuijk ${ }^{\mathrm{a}}$, Andrew H. Baker ${ }^{\mathrm{a}, \mathrm{b}}$, and Judith C. Sluimer ${ }^{\mathrm{a}, \mathrm{b}}$

Even the most sceptical cardiovascular scientists can now rest assured: LDL demonstrates a causal relationship to atherosclerotic cardiovascular disease (CVD) [1"']. A combined dataset of meta-analyses of over 200 cohort-based, mendelian randomization, and randomized trials covering 2 million subjects, followed for more than 20 million person years with more than 150000 major adverse cardiovascular events (MACEs) showed 1) a dose-dependent linear relationship between LDL-c levels and MACE, and 2) if LDL plasma particles are reduced without off-target effects, the risk of MACE is reduced. This is timely news in light of recent clinical outcomes concerning a new type of LDL-lowering compound, proprotein convertase subtilisin/kexin type 9 (PCKS9) antibody inhibitors, such as evolocumab, bococizumab, and alirocumab [2-4]. These antibodies prevent degradation of the LDL receptor, lower plasma LDL by $\sim 60 \%$ on top of statin treatment, and associated MACE by $15 \%$ (reviewed in [5]). Although this represents one of the most effective and fastest developments in recent years, it remains that 74 patients need to be treated with evolocumab to prevent one major event. This leaves considerable room for new therapeutic approaches. This could possibly be provided by anti-inflammatory treatment, such as IL1- $\beta$ inhibitor canakinumab, clinical results of which are eagerly awaited at ESC 2017 $[6,7]$. Nevertheless, more insight in the pathogenesis of atherosclerosis is still warranted and a welcome recommendation on the design, execution, and reporting of murine atherosclerosis studies will ensure reproducibility of animal pathogenesis studies and, hopefully, improve translation of mechanisms to human disease $\left[8,9^{-"}\right]$.

Growing evidence points toward the highly plastic nature of vascular smooth muscle cells (SMCs) [10-12], endothelial cells [13], and macrophages [14] in the development of experimental atherosclerosis. Adding to recent insights on plaque macrophages originating, at least partly, from cholesterol-loaded SMC [10-12], recent papers now report on a reciprocal transition between adventitial progenitors and plaque-residing SMCs [15",16"']. Majesky et al. show evidence to support SMCs as the source of a subpopulation of adventitial progenitors $\left[16^{m}\right]$, while previous reports support the reverse transition $\left[15^{\circ}\right]$.

In addition, the contribution of proliferation and clonal expansion of resident vessel wall cells receives increasing attention. Chappell et al. show conclusively that Acta2+ and MAC3+ SMC populations in lesions can arise from a subset of Myh11+ SMCs visualized by multicolor lineage labelling in mice [17"']. However, Gomez and Owens addressed some further clarifications that are needed in their accompanying editorial, concerning clonal expansion versus clonal selection and the mechanistic contribution of such defined populations to SMC function and lesion development, necessitating further research [18"].

Related to clonal expansion, two studies now show compelling evidence that an ageing-associated mutation of TET 2 in bone marrow can cause clonal hematopoiesis and accelerate murine atherosclerosis $\left[19^{"}, 20^{" \prime}\right]$. Moreover, patients with otherwise unexplained clonal hematopoiesis have a two-fold higher risk of coronary heart disease [20"']. As this mutation is associated with early-onset myocardial infarction, monitoring of clonal expansion and mutation analysis might improve current risk prediction.

The amount of factors influencing plaque progression is still greatly underestimated and further research into key mechanisms including cell plasticity and clonal expansion is still needed. New therapy strategies to combine with existing therapies could greatly improve patient treatment.

\footnotetext{
${ }^{a}$ CARIM School for Cardiovascular Diseases, Department of Pathology, Maastricht University Medical Center, Maastricht, The Netherlands and ${ }^{\mathrm{b}} \mathrm{BHF}$ Centre for Cardiovascular Science, University of Edinburgh, Edinburgh, UK

Correspondence to Dr Judith C. Sluimer, CARIM School for Cardiovascular Diseases, Department of Pathology, Maastricht University Medical Center, P.O. Box 5800, 6202 AZ Maastricht, The Netherlands.

Tel: +31 433877675; fax: +31 433876613;

e-mail: judith.sluimer@maastrichtuniversity.nl
}

Curr Opin Lipidol 2017, 28:520-521

DOI:10.1097/MOL.0000000000000462 


\section{Acknowledgements}

None.

\section{Financial support and sponsorship}

J.C.S. is funded by the Dutch heart foundation (2016T060) and member of a transatlantic network of excellence funded by the Leducq foundation. A.H.B. is supported by the British Heart Foundation as Chair of Translational Cardiovascular Sciences and the European Research Council.

\section{Conflicts of interest}

None.

\section{REFERENCES AND RECOMMENDED \\ READING}

Papers of particular interest, published within the annual period of review, have been highlighted as:

- of special interest

-1. of outstanding interest

1. Ference BA, Ginsberg HN, Graham I, et al. Low-density lipoproteins cause

-1. atherosclerotic cardiovascular disease. 1. Evidence from genetic, epidemiologic, and clinical studies. A consensus statement from the European Atherosclerosis Society Consensus Panel. Eur Heart J 2017; 38:2459-2472.

This meta-analysis finally and conclusively shows the causal role for LDL cholesterol in CVD.

2. Sabatine MS, Giugliano RP, Keech AC, et al. Evolocumab and clinical outcomes in patients with cardiovascular disease. N Engl J Med 2017; 376:1713-1722.

3. Ridker PM, Revkin J, Amarenco P, et al. Cardiovascular efficacy and safety of bococizumab in high-risk patients. N Engl J Med 2017; 376:1527-1539.

4. Robinson JG, Farnier M, Krempf M, et al. Efficacy and safety of alirocumab in reducing lipids and cardiovascular events. N Engl J Med 2015; 372: 1489-1499.

5. Cupido AJ, Reeskamp LF, Kastelein JJP. Novel lipid modifying drugs to lower LDL cholesterol. Curr Opin Lipidol 2017; 28:367-373.

6. Peiro C, Lorenzo O, Carraro R, Sanchez-Ferrer CF. IL-1beta inhibition in cardiovascular complications associated to diabetes mellitus. Front Pharmacol 2017; 8:363.

7. Choudhury RP, Birks JS, Mani V, et al. Arterial effects of canakinumab in patients with atherosclerosis and type 2 diabetes or glucose intolerance. J Am Coll Cardiol 2016; 68:1769-1780.

8. Daugherty A, Tall AR, Daemen M, et al. Recommendation on design, execution, and reporting of animal atherosclerosis studies: a scientific statement from the American Heart Association. Arterioscler Thromb Vasc Biol 2017; 37:e131-e157.
9. Daugherty $A$, Tall $A R$, Daemen $M$, et al. Recommendation on design,

- execution, and reporting of animal atherosclerosis studies: a scientific statement from the American Heart Association. Circ Res 2017; 121: e53-e79.

This consensus statement provides guidelines which should be widely adopted by scientists using animal models of atherosclerosis.

10. Shankman LS, Gomez D, Cherepanova OA, et al. KLF4-dependent phenotypic modulation of smooth muscle cells has a key role in atherosclerotic plaque pathogenesis. Nat Med 2015; 21:628-637.

11. Feil $S$, Fehrenbacher $B$, Lukowski $R$, et al. Transdifferentiation of vascular smooth muscle cells to macrophage-like cells during atherogenesis. Circ Res 2014; 115:662-667.

12. Vengrenyuk $Y$, Nishi $H$, Long $X$, et al. Cholesterol loading reprograms the microRNA-143/145-myocardin axis to convert aortic smooth muscle cells to a dysfunctional macrophage-like phenotype. Arterioscler Thromb Vasc Biol 2015; 35:535-546.

13. Evrard SM, Lecce L, Michelis KC, et al. Endothelial to mesenchymal transition is common in atherosclerotic lesions and is associated with plaque instability. Nat Commun 2016; 7:11853.

14. Albarran-Juarez J, Kaur $\mathrm{H}$, Grimm $M$, et al. Lineage tracing of cells involved in atherosclerosis. Atherosclerosis 2016; 251:445-453.

15. Kramann R, Goettsch $C$, Wongboonsin J, et al. Adventitial MSC-like cells are

- progenitors of vascular smooth muscle cells and drive vascular calcification in chronic kidney disease. Cell Stem Cell 2016; 19:628-642.

This report is important as it is definitive evidence that adventitial progenitors, beyond their mere presence in plaques, have a causal function in arterial calcification upon chronic kidney disease in mice

16. Majesky MW, Horita $H$, Ostriker A, et al. Differentiated smooth muscle cells

-. generate a subpopulation of resident vascular progenitor cells in the adventitia regulated by Klf4. Circ Res 2017; 120:296-311.

Although SMCs as cell of origin for other vascular cells in atherosclerosis has been described; this article shows the other side of the coin: SMCs can migrate to an adventitial niche and as a consequence loose their SMC markers and gain progenitor markers by upregulation of KLF4.

17. Chappell J, Harman JL, Narasimhan VM, et al. Extensive proliferation of a

- subset of differentiated, yet plastic, medial vascular smooth muscle cells contributes to neointimal formation in mouse injury and atherosclerosis models. Circ Res 2016; 119:1313-1323.

This study shows, by making use of multicolor labeling, that a single SMC can give rise to different subpopulations by clonal expansion in atherosclerotic lesions.

18. Gomez D, Owens GK. Reconciling smooth muscle cell oligoclonality and

- proliferative capacity in experimental atherosclerosis. Circ Res 2016; 119:1262-1264.

This review addresses whether creation of SMC subpopulations in the plaque as described by Chappell et al. is a consequence of clonal expansion or if this is a consequence of obtained epigenetic advantages.

19. Fuster JJ, MacLauchlan S, Zuriaga MA, et al. Clonal hematopoiesis associated

- with TET2 deficiency accelerates atherosclerosis development in mice. Science 2017; 355:842-847.

This study reports the causal role for ageing-associated mutations in clonal hematopoiesis and murine atherogenesis.

20. Jaiswal S, Natarajan $P$, Silver AJ, et al. Clonal hematopoiesis and risk

.1. of atherosclerotic cardiovascular disease. N Engl J Med 2017; 377: $111-121$.

The authors demonstrated a two-fold increased risk human CVD for unexplained clonal hematopoiesis and ageing-associated mutations, as well as a causal role in murine atherogenesis.

\section{FURTHER RECOMMENDED READING}

Rahman K, Vengrenyuk Y, Ramsey SA, et al. Inflammatory fly6Chi monocytes and - their conversion to M2 macrophages drive atherosclerosis regression. J Clin Invest 2017; 127:2904-2915.

This article clarifies the source of, and molecular triggers in macrophages driving inflammation resolution in regression of murine atherosclerosis, knowledge that may be used to drive plaques into regression

Di Gregoli K, Mohamad Anuar NN, Bianco R, et al. MicroRNA-181b controls

- atherosclerosis and aneurysms through regulation of TIMP-3 and Elastin. Circ Res 2017; 120:49-65.

This article shows miRNA function in atherosclerosis extends beyond lipoprotein biology.
Ouimet M, Ediriweera $\mathrm{H}$, Afonso MS, et al. microRNA-33 regulates macrophage - autophagy in atherosclerosis. Arterioscler Thromb Vasc Biol 2017; 37: 1058-1067.

This article shows miRNA function in atherosclerosis extends beyond lipoprotein biology.

Eken SM, Jin H, Chernogubova $\mathrm{E}$, et al. MicroRNA-210 enhances fibrous cap - stability in advanced atherosclerotic lesions. Circ Res 2017; 120:633-644. This article shows miRNA function in atherosclerosis extends beyond lipoprotein biology.

Canfran-Duque A, Rotllan N, Zhang X, et al. Macrophage deficiency of miR-21

- promotes apoptosis, plaque necrosis, and vascular inflammation during atherogenesis. EMBO Mol Med 2017; 9:1244-1262.

This article shows miRNA function in atherosclerosis extends beyond lipoprotein biology. 